\title{
DOE V. METROPOLITAN TORONTO BOARD OF Commissioners of Police AND THe Status OF Public Oversight of the Police in Canada
}

\author{
Scott Childs* and Paul Ceyssens**
}

\section{INTRODUCTION}

The judgment of the Ontario Court (General Division) in Doe v. Metropolitan Toronto Board of Commissioners of Police ${ }^{1}$ has generated an unusually high level of publicity. The case presents a timely opportunity to reflect on the results of recent legal developments in the area of accountability of the police. Doe, of course, is a case in which a person used the civil law process to seek redress. As we discuss below, a myriad of other legal processes exist.

Doe raises several prominent issues in police oversight, most notably the availability of damages under the Charter of Rights and Freedoms and a potentially onerous new duty on the police to warn potential victims of crime. This article will examine the significance of this judgment in light of recent trends in the legal accountability of the police and its impact on policy decisions for police forces and their governing bodies.

\section{The FACTS AND THE FINDINGS}

The facts of the Doe case are not complex. In 1986, Jane Doe was attacked by a serial rapist. She sued, alleging that the two police investigators were responsible for her injuries. She also sued the chief of police, the governing body of the police force, and the Board of Commissioners of Police. Since the serial rapist confined his attacks to a small geographic area and an easily identifiable class of victims, Doe argued that she had become "part of a narrow and distinct group of potential victims," (the victims were all single, white women who resided in second or third floor apartments with accessible balconies that had been used to gain access).

Doe claimed damages on two grounds. First, she maintained that the police were negligent in that they failed to warn her of a danger that they knew (or ought to have known) existed or, absent such a warning, that they failed to protect her adequately against the danger. Secondly, she alleged the police breached her rights guaranteed under ss. 7 and 15(1) of the Charter of Rights and Freedoms, which provide as follows:

- B.Sc., LL.B., of the Ontario Bar. Member of the Ontario Provincial Police and a former member of the Metropolitan Toronto Police. Served as a law clerk at the Ontario Court of Appeal and practiced as Crown Counsel with the Federal Department of Justice.

-* $\quad$ B.A., LL.B., of the British Columbia and Ontario Bars. Practiced with the Ontario Ministry of the Attorney General and is now in private practice in British Columbia. The authors wish to express their appreciation to Professor Patrick J. Knoll, Q.C., Faculty of Law, University of Calgary, for his valuable suggestions and comments.

1 (1998), 160 D.L.R. (4th) 697, 39 O.R. (3d) 487 [hereinafter Doe] 
7. (1) Everyone has the right to life, liberty and security of the person and the right not to be deprived thereof except in accordance with the principles of fundamental justice.

15. (1) Every individual is equal before and under the law and has the right to the equal protection and equal benefit of the law without discrimination and, in particular, without discrimination based on race, national or ethnic origin, colour, religion, sex, age or mental or physical disability.

The defendants made unsuccessful preliminary attempts to dismiss the civil action. ${ }^{2}$ An eight-week trial occurred in late 1997, and the Ontario Court (General Division) awarded judgment in favour of Jane Doe on July 3, 1998.

The Court rejected the evidence of the police that they did not warn women they knew to be at risk on the basis that the attacker would relocate and continue to offend. Rather, the Court concluded that "the real reason a warning was not given in the circumstances of this case was because [the investigators] believed that women living in the area would become hysterical and panic, and their investigation would thereby be jeopardized." ${ }^{.3}$ In a parallel investigation into similar (though more violent) attacks elsewhere in the city, different investigators in the same police force issued a series of effective public warnings to alert potential victims.

The Court found the police negligent in the circumstances of this case. The Court ruled that police could have and should have provided a "meaningful" warning to the women who were at particular risk:

That warning could have been by way of canvass of their apartments, by a media blitz, by holding widely publicized public meetings or any one or a combination of these methods. Such warning should have alerted the particular women at risk, and advised them of suggested precautions they might take to protect themselves. ${ }^{4}$

The Court noted that the police owe a duty to prevent crime as well as a duty to protect life and property and made the following observation:

[T]he police failed utterly in their duty to protect these women and [Jane Doe] in particular from the serial rapist the police knew to be in their midst by failing to warn so that they may have had the opportunity to take steps to protect themselves.

It is no answer for the police to say women are always at risk and as an urban adult living in downtown Toronto they have an obligation to look out for themselves. Women generally do, everyday of their lives, conduct themselves and their lives in such a way as to avoid the general pervasive threat of male violence which exists in our society. Here police were aware of a specific threat or risk to a

$2 \quad$ Doe v. Metropolitan Toronto (Municipality) Commissioners of Police (1989), 58 D.L.R. (4th) 396 (H.C.J.), aff'd (1990), 74 O.R. (2d) 225, 72 D.L.R. (4th) 580 (Div. Ct.), aff'd (1991), 1 O.R. (3d) 416 (C.A.).

$3 \quad$ Supra note 1 at 730 .

$4 \quad$ Ibid. 
specific group of women and they did nothing to warn those women of the danger they were in, nor did they take any measures to protect them. ${ }^{5}$

The Court then went on to find that the police had breached Doe's Charter rights. In particular, the Court held that:

[Police] deprived [Jane Doe] of her right to security of the person by subjecting her to the very real risk of attack by a serial rapist - a risk of which they were aware but about which they quite deliberately failed to inform the plaintiff [or other women] and where in the face of that knowledge and their belief that the rapist would certainly attack again, they additionally failed to take any steps to protect the plaintiff or other women like her. ${ }^{6}$

Likewise, on the issue of equality rights as guaranteed by s. 15(1) of the Charter, the Court concluded as follows:

[T] he conduct of this investigation and the failure to warn in particular, was motivated and informed by the adherence to rape myths as well as sexist stereotypical reasoning about rape, about women and about women who are raped. [Jane Doe] therefore has been discriminated against by reason of her gender and as the result [her] rights to equal protection and equal benefit of the law were compromised. ${ }^{7}$

The Court made one award of general damages - $\$ 175,000$ - for both the negligence and the violation of Jane Doe's Charter rights, as well as other smaller awards of damages.

\section{Doe and Recent Trends in Police Civil Liability}

The past ten to fifteen years have seen dramatic change in the legal landscape of policing in Canada. This change is evident in nearly every facet of the legal regulation of the police - in some cases the legal developments have been both sudden and very profound. Some of this change has occurred through the civil law process.

Despite the extensive publicity afforded the Doe case, however, it should not be seen as the dawn of a new age of police accountability through the civil law process. Although Doe does set important new ground in two particular areas, ${ }^{8}$ the significance of the case should not be overstated, and it is more properly viewed as one in a large number of recent cases where the civil courts have examined an important aspect of police conduct in detail and found it wanting.

Indeed, the trends in police civil liability can be summarized in five statements:

Ibid. at 732 .

Ibid. at 734 .

Ibid.

As discussed below. 
1. civil actions against the police have significantly increased in number in the past ten years;

2. many of these cases are unprecedented - they involve novel causes of action that have not previously been the subject of civil claims against the police;

3. courts of law are awarding judgment against the police in many important cases;

4. courts of law are making large awards of damages and costs against the police;

5. other similar cases often follow on the heels of a successful plaintiff.

Doe, then, is one example of this trend, albeit a conspicuous example. It occurred in the past ten years, it involved a cause of action that had not previously been ruled upon by a court of law in Canada, ${ }^{9}$ the court awarded judgment against the police, and significant damages resulted. However, the civil courts have scrutinized many other areas of police activity in recent years.

One such emerging area is negligent investigation. In a number of cases, persons who have been charged by the police have sued in negligence after criminal proceedings have been disposed of in their favour. The leading judgment in this area is Beckstead v. Ottawa (City). ${ }^{10}$ There, police charged Beckstead with two criminal offences relating to the use of an acquaintance's bank card. The investigation was deficient in a number of respects: the security photo of the suspect showed a person who did not resemble Beckstead, police did not interview the victim, and the police officer who charged Beckstead decided to charge her even before he interviewed her. Beckstead attended court on eight occasions over a period of six months before the Crown withdrew the charges. In its judgment, the trial court allowed the claim of negligence, stating that police owed a duty to "perform a careful investigation of the complaint" before laying a charge. The Ontario Court of Appeal, in a very brief judgment, dismissed the Board's appeal. It agreed with the trial judge, concluding that "[t]he police officer acted with indifference to the consequences of laying the charge and fell short of even the rudimentary steps which might have been taken to establish reasonable and probable grounds." "The Court also dismissed an appeal against the award of general damages, concluding that the award of $\$ 20,000$ was "modest." 12 The

There was one earlier case in which the duty to victims of crime was raised in what appears to be an almost incidental manner: Danzas (Canada) Ltée v. Canada, [1986] 1 C.T.C. 174, 10 C.E.R. 10 (Fed. T.D.), aff'd (1987), 9 A.C.W.S. (3d) 190 (Fed. C.A.). In this case, the plaintiff shipped a quantity of gems which disappeared through the efforts of a smuggling ring. The plaintiff alleged that the R.C.M.P. was negligent in performing its duty to prevent crime since it knew of three recent similar incidents. Although the Court concluded that the police were not at fault in the circumstances, it did not explore in detail the extent of police duty to victims of crime. 
ultimate cost of this judgment, of course, is significantly higher, including as it does other damages, interest and costs. Beckstead represents a further illustration of contemporary trends: the case is recent, the cause of action is unprecedented, the plaintiff obtained judgment against the police, the court awarded significant damages to the plaintiff, and other similar decisions have since resulted. ${ }^{13}$

Another important development in police civil liability appears in the field of workplace harassment. The leading case is the decision of the Federal Court Trial Division in Clark v. Canada.$^{14}$ It represents the first time the civil law has been used to recover damages for harassment in the police workplace. ${ }^{15}$ Clark was an R.C.M.P. constable who experienced difficulty in the workplace shortly after she joined the force. In addition to ill-considered remarks and unjustly critical assessments of her performance, Clark experienced a wide variety of inappropriate conduct. Incidents of harassment continued after Clark was transferred to other duties. Her attempts to address her concerns with a number of her superiors were unsuccessful. When she met with one superior to seek a transfer on the basis of a recent asthma condition, the superior told her that she could quit, accept a medical discharge or he would see her terminated by the end of the year. On her second day after the meeting, her supervisor issued three formal negative performance comments, and these comments continued in large numbers thereafter. After medical advice confirmed that Clark was suffering from stress-related illness, she was posted to a second detachment on a temporary basis and then formally transferred to a third detachment. Her superiors found Clark's work satisfactory in both locations, and she experienced no incidents of harassment. Shortly after arriving at the third detachment, however, she learned that criminal investigations were being conducted into incidents involving the treatment of prisoners which occurred between two and five years earlier. The Court found that each of these incidents was known to her superiors when it occurred. Clark gave evidence that the investigations left her no alternative but to resign. Subsequent to her resignation, she was charged with assault in respect of two of the incidents but was acquitted at trial. The Court made the following finding:

My assessment of the evidence is that the plaintiff was in fact harassed by male constables and that her RCMP superiors failed to come to her assistance. I also find that the harassment was the major cause for her resignation. She did suffer from asthma and did indicate the condition was the reason

13 The other decisions have involved preliminary motions to strike a statement of claim and were not judgments following a full trial of the action. See, for example, Reynen v. Canada (Attorney General) (1993), 70 F.T.R. 158, rev'd in part (1995), 184 N.R. 350 (Fed. C.A.). Nearly all of these cases are decided in favour of the plaintiff. The one notable exception appears in the judgment of the New Brunswick Court of Appeal in McGillivray v. New Brunswick (1994), 116 D.L.R. (4th) 104, 149 N.B.R. (2d) 311. Negligent investigation carries the potential of replacing malicious prosecution as a means of addressing improper police investigations since malicious prosecution is extremely difficult to establish. Only rarely do courts of law award judgment in favour of plaintiffs in such actions. See P. Ceyssens, Legal Aspects of Policing (Saltspring Island: Earlscourt, 1994) at s. 3.9 [hereinafter Legal Aspects of Policing].

14 [1994] 3 F.C. 323, 76 F.T.R. 241 [hereinafter Clark cited to F.C.].

is The significance of this judgment is not, obviously, restricted to the police. Clark, ibid., is the first judgment in which the civil law was successfully used to recover damages for harassment in any workplace. 
for her transfer request. She also informed some people that she had resigned because of her sickness, but the real cause for her resignation was stress, depression and anxiety caused by harassment on the part of male members of the RCMP and failure to intervene by her superiors. ${ }^{16}$

Clark successfully sued the Crown for the tort of intentional infliction of nervous shock. In addition to an award of $\$ 88,000$ for lost earnings, the Court awarded Clark $\$ 5,000$ general damages for her injured dignity arising from the tortious conduct.

Negligent supervision is a third area which has seen important developments in the past few years. This issue was also addressed in the Clark decision. In addition to finding for Clark on the issue of intentional infliction of nervous shock, the Court also concluded that the evidence established negligence on the part of her supervisors:

[T] here is no doubt that as the plaintiff's immediate supervisor, Cpl. Mazur owed the plaintiff a duty of care and breached that duty consistently. I find that over a lengthy period, he deliberately refused to exercise his authority to put an end to the conduct of harassment of which he was well aware and which he in fact participated in on occasion, thus condoning that behaviour. He further neglected utterly to respond to the plaintiff's distress signals as his position of responsibility required him to do. And, as mentioned earlier, superior RCMP officers failed to come to the plaintiff's assistance. ${ }^{17}$

The issue of negligent supervision has also arisen in a context where a member of the public has suffered damages. In Berntt v. Vancouver (City), ${ }^{18}$ the Court considered an allegation of negligent supervision in a case where police had shot a rioter with an Arwen riot gun. The Court concluded that the plaintiff had proved that a duty of care existed but had not proved a breach of the appropriate standard of care. ${ }^{19}$

Police pursuits have also been the subject of civil actions in recent years. While civil actions against the police in this regard were not unheard of prior to the last ten years ${ }^{20}$ the last several years have seen a number of important decisions. In the one recent appellate judgment on police pursuits, the Court upheld a trial judgment that harshly criticized police conduct in a pursuit which ended in the pursued driver colliding with an innocent motorist, resulting in the death of the former and severe injuries to the innocent motorist. The Court found the police 25 percent liable in the collision. ${ }^{21}$

Ibid. at 336 .

Ibid. at 355-56.

(1997), 28 B.C.L.R. (3d) 203 (S.C.) [hereinafter Berntt].

Ibid. at 253-61. A related issue is negligent training, which has generated considerable litigation in recent years. See Berntt, ibid. and the discussion in Legal Aspects of Policing, supra note 13 at s. 3.19 .

See, for example, Ontario (Attorney General) v. Keller (1978), 23 O.R. (2d) 143, 94 D.L.R. (3d) 632 (C.A.); Pepper v. Hoover (1976), 71 D.L.R. (3d) 129 (Alta. T.D.).

Doern v. Phillips (Estate) (1997), 43 B.C.L.R. (3d) 53 (C.A.), aff'g [1995] 4 W.W.R. 1, 2 B.C.L.R. (3d) 349 (S.C.). See also Blaz v. Dickinson (1996), 23 M.V.R. (3d) 70 (Ont. Ct. (Gen. Div.)); Noel (Committee of) v. Botkin, [1995] 7 W.W.R. 479, 9 B.C.L.R. (3d) 21 (S.C.); Jones v. Denomme (1994), 46 A.C.W.S. (3d) 1072. 
Litigation arising from police use of force provides another illustration of the trends of the past ten years. While civil litigation arising from use of firearms by police is not new, ${ }^{22}$ police are now being sued for injuries arising from use of the baton, ${ }^{23}$ pepper spray, ${ }^{24}$ dogs, ${ }^{25}$ the full-nelson hold, ${ }^{26}$ weapons of opportunity, ${ }^{27}$ the Arwen antiriot weapon, ${ }^{28}$ emergency response team operations ${ }^{29}$ and other methods of force. Courts of law have made very large awards of damages in several recent cases involving use of force by police. ${ }^{30}$

Recent years have also seen several noteworthy civil decisions dealing with care of persons in police custody. ${ }^{31}$ In one case, Kirby v. British Columbia (Attorney General), ${ }^{32}$ police found Kirby passed out, slumped over the steering wheel of his van. They opened his door, roused him and assisted him out of the van. After placing him on the ground next to the van and searching the van, they proceeded to raise him to his feet and search him. A police officer held him up against the van, searched him and then released him to secure the van. Kirby fell backwards, struck his head on the hard pavement, and suffered serious injury. The Court concluded that the police officer breached his duty to take reasonable care for Kirby's safety when, "knowing Mr. Kirby to be severely intoxicated and unsteady on his feet, he left him unattended and leaning against the van." ${ }^{33}$ In another case, police arrested the plaintiff for being intoxicated in a public place after a house party. Shortly before the arrest, the plaintiff had seriously injured his leg. While in custody, he had complained of leg pain but was not taken to hospital for several hours. Ultimately his left leg was amputated. When the police officer initially arrested the plaintiff, he did not make extensive inquiries of the other persons at the scene, given the plaintiff's extreme belligerence. The Court ruled that the arresting police officer had not discharged his duty to make "reasonably relevant inquiries" as to the plaintiff's inability to stand or walk. The Court also found the guard negligent on the basis that the plaintiff was "yelling, whining, crying, cursing

See Legal Aspects of Policing, supra note 13 at s. 3.4(d).

See, for example, Allarie v. Victoria (City), [1995] 1 W.W.R. 655 (B.C.S.C.) and Kent-Snowsell v. Kennedy, [1997] B.C.J. No. 1541.

Christopherson v. Saanich (District), [1995] 4 W.W.R. 381 (B.C.S.C.).

C. (T.L.) v. Vancouver (City) (1995), [1996] 2 W.W.R. 529, 13 B.C.L.R. (3d) 201 (S.C.); Arnault v. Prince Albert (City) Board of Police Commissioners (1995), [1996] 4 W.W.R. 38, 136 Sask. R. 49 (Q.B.); Fennell v. Victoria (City) (1996), 64 A.C.W.S. (3d) 469 (B.C. S.C.).

See, for example, Green v. Lawrence (1997), 119 Man. R. (2d) 81 (Q.B.), var'd [1998] M.J. No. 335 (C.A.).

See Nault v. Tremblay, [1995] B.C.W.L.D. 1368 (S.C.) and Marshall v. Monpetit, ( April 1997) (Ont. C.A.) (use of metal flashlight as police instrument of force).

Berntt, supra note 18.

See Vukelic v. Canada (1997), 29 B.C.L.R. (3d) 288 (C.A.); Rabideau v. Maddocks (1992), 37 A.C.W.S. (3d) 754 (Ont. Ct. (Gen. Div.)).

See, for example, Green v. Lawrence, supra note 26; Vukelic v. Canada, ibid; Rabideau v. Maddocks, ibid.

See generally Legal Aspects of Policing, supra note 13 at s. 3.12.

(1997), 41 B.C.L.R. (3d) 45 (S.C.).

Ibid. at 52 . The Court also concluded that the plaintiff was not contributorily negligent: "while the plaintiff placed himself in a position of potential danger, he did not suffer injuries in that position. Rather, he did so through the intervening act of [the police officer] in propping the plaintiff up against the van and in abandoning him in that position knowing him to be incapable" (ibid. at 54). 
and mumbling" for three hours, which should have alerted the guard to the fact that the plaintiff was in pain. ${ }^{34}$ Finally, a third case examined the extent of police duty when the person refuses medical attention. ${ }^{35}$ The plaintiff, who was drunk, fell and struck his head on the ground while walking home in the early hours of the morning. A constable and two ambulance attendants found a "drunk, angry, aggressive, profane and obstinate" plaintiff with some blood matted in his hair and some on his shoulder. He refused to go to the hospital and was eventually arrested. At the police station, the police made no further attempt to arrange medical attention for the plaintiff but did observe him on a regular basis. He did not respond when he was roused in the morning, and medical examination revealed a depressed skull fracture resulting in serious brain injury. The Court found that the skull fracture would have been discovered and treated had the plaintiff received medical treatment upon or shortly after arrest. In this case, however, the plaintiff had strenuously refused such treatment. The Court ruled that although a person in custody may elect to refuse medical attention, the person must be capable of making such a decision in a rational way. Given the plaintiff's condition, the police knew or should have known that he was not capable of making a rational decision regarding hospital treatment, and they should have ensured such treatment, using force if necessary. The Court made a large award of damages in each of these cases.

Obviously, the above examples of recent cases in police civil liability are not intended to be exhaustive. ${ }^{36}$ They are only intended to illustrate the substantial developments in police oversight by the civil courts in recent years. The trend is now well established. Doe v. Metropolitan Toronto Board of Commissioners of Police is but the latest example of this trend.

Much ink has been spilled over whether this trend makes good policy in law. Some would suggest that despite recent progress, more is required to make the civil law process a fully satisfactory vehicle to address deficiencies in police behaviour. ${ }^{37}$ Others would suggest that the present level of oversight through the civil law process is sufficient or even excessive. In Hill v. Chief Constable of West Yorkshire ${ }^{38}$ the English House of Lords favoured restraint in judicial post-mortems of police investigations. In facts similar to Doe, an offender murdered thirteen women over a five-year period, including the plaintiff's daughter. Most of these crimes occurred in the chief constable's jurisdiction. Hill claimed damages against the chief constable for

Lipcsei v. Central Saanich (District) (1994), [1995] 7 W.W.R. 582, 8 B.C.L.R. (3d) 325 (S.C.). The court concluded that the police officer was 30 percent responsible for the injury, and the guard 10 percent responsible. Lejeune v. Police Regionale de Beresford, Nigadoo (1998), 196 N.B.R. (2d) 371, 501 A.P.R. 501 (Q.B.) (negligent disclosure of informant's name).

${ }^{37}$ Whatever the ultimate results in individual civil actions against the police, a compelling argument may be made that the institutional rigidity of the litigation process seriously affects the role of the civil law as an effective oversight tool. While the Doe case may be an unusual example, over eleven years passed between issuance of the statement of claim and judgment. 
negligence, arguing that the police failed to apprehend the attacker in a timely manner and prevent the murder of her daughter. In finding that legal responsibility should not be placed at the feet of the investigators, their Lordships relied on the second stage of the classic Anns test: ${ }^{39}$

The general sense of public duty which motivates police forces is unlikely to be appreciably reinforced by the imposition of such liability so far as concerns their function in the investigation and suppression of crime. From time to time they make mistakes in the exercise of that function, but it is not to be doubted that they apply their best endeavours to the performance of it. In some instances the imposition of liability may lead to the exercise of a function being carried on in a detrimentally defensive frame of mind. The possibility of this happening in relation to the investigative operations of the police cannot be excluded. Further it would be reasonable to expect that if potential liability were to be imposed it would be not uncommon for actions to be raised against police forces on the ground that they had failed to catch some criminal as soon as they might have done, with the result that he went on to commit further crimes. While some such actions might involve allegations of a simple and straightforward type of failure - for example that a police officer negligently tripped and fell while pursuing a burglar - others would be likely to enter deeply into the general nature of a police investigation, as indeed the present action would seek to do. The manner of conduct of such an investigation must necessarily involve a variety of decisions to be made on matters of policy and discretion, for example as to which particular line of inquiry is most advantageously to be pursued and what is the most advantageous way to deploy the available resources. Many such decisions would not be regarded by the courts as appropriate to be called in question, yet elaborate investigation of the facts might be necessary to ascertain whether or not this was so. A great deal of police time, trouble and expense might be expected to have to be put into the preparation of the defence to the action and the attendance of witnesses at the trial. The result would be a significant diversion of police manpower and attention from their most important function, that of the suppression of crime. Closed investigations would have to be reopened and retraversed, not with the object of bringing any criminal to justice but to ascertain whether or not they had been competently conducted. ${ }^{40}$

\section{Recent Trends in Other Mechanisms of Police Oversight}

The civil courts represent, of course, only one mechanism by which police activity may be monitored. Other established and effective methods exist to regulate police behaviour. Some of these methods involve the judiciary in different forums and others utilize quasi-judicial administrative boards and tribunals. Most have seen considerable evolution in the past fifteen years.

The internal police discipline and public complaint processes play a prominent role in regulating police conduct. Most jurisdictions have seen significant legislative at 498 , in which Lord Wilberforce set out the two-stage test to determine whether a duty of care exists in a particular situation. The first stage is to examine whether the requisite degree of proximity exists. If the answer is yes, then it is necessary to consider the second stage: whether a public policy "immunity" exists in the circumstances. 
amendments in this regard in the past fifteen years. ${ }^{41}$ In particular, decisions of courts of law and administrative tribunals are demonstrably more numerous ${ }^{42}$ and complex, and many involve matters of first impression. Tribunals have considered not only "traditional" issues such as use of force ${ }^{43}$ but also more contemporary issues such as workplace discrimination and harassment ${ }^{44}$ discrimination in the delivery of police services ${ }^{45}$ and the effects of handicap. ${ }^{46}$ Examinations of systemic discipline and complaint issues have also occurred ${ }^{47}$ Also, the past fifteen years have seen the police discipline process move from a punitive model toward a remedial model. ${ }^{48}$ Discipline schemes in a number of jurisdictions, moreover, have now evolved to consider not only the conduct of a particular police officer, but also whether the incident motivating the investigation reveals organizational or administrative practices within a police agency which require consideration. ${ }^{49}$ Many jurisdictions now permit remedial dispositions in discipline matters in addition to traditional military-style punishments. ${ }^{50}$

41 Ontario, for example, has seen four significant pieces of legislation since 1981: Metropolitan Toronto Police Force Complaints Project Act, 1981, S.O. 1981, c. 43; Metropolitan Toronto Police Force Complaints Act, 1984, S.O. 1984, c. 63; Police Services Act, 1990, S.O. 1990, c. 10; Police Services Amendment Act, 1997, S.O. 1997, c. 8.

For example, a considerable body of Divisional Court jurisprudence has resulted in recent years from appeals of decisions of boards of inquiry constituted under the former Part VI of the Police Services Act and predecessor complaint schemes (the Metropolitan Toronto Police Force Complaints Act, 1984 and the Metropolitan Toronto Police Force Complaints Project Act, 1981, ibid.).

43 Tribunal decisions contain detailed examinations of particular modes of force. See Harty $\mathbf{v}$ Kroeker (9 March 1988), No. 43-97 (Alta. L.E.R.B.) (pepper spray), and Re Cooper (26 June 1992) Files 2000-PCC-89557 and 2000-PCC-89558 (R.C.M.P. Public Complaints Commission) (carotid restraint techniques). See Drennan and Hamilton-Wentworth Regional Police, (6 August 1994) (O.C.C.P.S.); Howat and Ontario Provincial Police (1990), 2 O.P.R. 877. Muojekwu v. Sim and Yip, (3 May 1996) B.C. Police Commission; Gray v. Wilson, (14 September 1989) Ont. Bd. Inq. See Marsden and Metropolitan Toronto Police (14 April 1994) (O.C.C.P.S.) (alcoholism) and Reilly and Brockville Police (12 May 1997) (O.C.C.P.S.) (depression), for example. See Inquiry into Administration of Internal Investigations by the Metropolitan Toronto Police (the "Junger Inquiry") (August 1992) (O.C.C.P.S.).

On the issue of the distinction between the punitive and remedial models, see Canada, The Report of the Commission of Inquiry Relating to Public Complaints, Internal Discipline and Grievance Procedure Within the Royal Canadian Mounted Police (Ottawa: Information Canada, 1976) at 13435 (the "Marin" Report).

One example appears in N.S. Reg. 135/94, s. 12(11), which provides that "[t]he investigator shall also identify any organizational or administrative practices of the police force which may have caused or contributed to the disciplinary default and the chief officer or his delegate shall consider independently of the disposition of the disciplinary default all matters of a purely organizational or administrative nature which may need further consideration and report these matters, together with their disposition, to the board and the Commission." See also B.C. Reg. 330/75, ss. 11(4), 12. The Ontario Police Services Act, supra note 41, for example, now permits (among other dispositions) "specified counselling, treatment or training" (s. 68(5)(b)) and participation in "a specified program or activity" (s. 68(5)(c)). The authority to require "counselling, treatment or training" in discipline cases also appears in ss. 58(1)(f) and 58(2)(c) of the Saskatchewan Police Act, 1990, and N.S. Reg. 135/94, s. 5(3)(h) (members of police forces other than chief officers) and s. 5(4)(e) (chief officers). In Alberta, Alta. Reg. 356/90, s. 17(3) provides that "... the cited officer may also be directed to undertake special training or professional counselling." Newfoundland has a similar approach: s. 16(2) of the Royal Newfoundland Constabulary 
The trends of recent years in civil actions against the police are also evident in human rights litigation involving the police. The earliest human rights decisions involving the police ${ }^{51}$ are scarcely twenty years old, and two-thirds of police-related human rights decisions have occurred within the past ten years. Among the more prominent complaints are those involving recruitment issues, ${ }^{52}$ pregnancy-based discrimination, ${ }^{53}$ accommodation of disabled constables $^{54}$ and other workplace issues. $^{55}$

Increasingly aggressive oversight of police activities has been exercised by the criminal courts as well. Since its proclamation in 1982, criminal courts at every level have made extensive use of the powerful provisions of the Charter to punish police misconduct. Police procedures considered entirely acceptable twenty years ago have fallen victim to the increased desire for regulation and public accountability. Criminal court judgments have often lead to significant statutory change, both in the Criminal $\mathrm{Code}^{56}$ and in provincial police legislation. For example: police may no longer enter a private residence to effect an arrest without a warrant, ${ }^{57}$ collect samples of tissue from an accused for DNA analysis without a warrant ${ }^{58}$ or shoot at a fleeing felon without reasonable grounds to believe an imminent danger exists. ${ }^{59}$

Finally, recent trends towards increased public oversight of the police have manifested themselves in one jurisdiction in the creation of a public agency that directly investigates suspected criminal conduct by police. Part VII of the Ontario Police Services $A c t^{60}$ created the "Special Investigations Unit" (S.I.U.), a public agency charged with investigating "circumstances of serious injuries and deaths that may have resulted from criminal offences committed by police officers." ${ }^{61}$ Police officers are required by the same enabling provision to "cooperate fully" with the S.I.U. and its investigators. ${ }^{62}$ Unfortunately, this particular mechanism of supervision has generated

Regulations, C.N.R. 802/96, permits a disciplinary panel in certain cases to order a police officer to "participate in the program or activity that the panel feels appropriate."

Ryan v. Board of Inquiry under the Human Rights Act (1976), 22 N.S.R. (2d) 444, 31 A.P.R. 444 (T.D.); Colfer v. Ottawa (City) Board of Commissioners of Police (12 January 1979) (Ont. Bd. of Inq.).

Cotterall v. Vancouver Police Board (1994), 26 C.H.R.R. D/510 (B.C.H.R.C.) (eyesight) and Patry v. Royal Canadian Mounted Police (21 February 1995) (C.H.R.T.) (hearing standards), for example.

Lord v. Haldimand-Norfolk Police Services Board (1995), 23 C.H.R.R. D/500 (Ont. Bd. Inq.); Orangeville Police Association and Orangeville Police Services Board (1994), 40 L.A.C. (4th) 269. Krznaric v. Chevrette (1997), 154 D.L.R. (4th) 527 (Ont. Ct. (Gen. Div.)); Barnard v. Fort Frances (Town) Board of Commissioners of Police (1987), 9 C.H.R.R. D/4845 (Ont. Bd. Inq.). Grant v. The Queen (1994), 81 F.T.R. 195, aff'd (1995), 125 D.L.R. (4th) 556 (Fed.C.A.) (modification of uniform on religious grounds); Large v. Stratford (City), [1995] 3 S.C.R. 733, 128 D.L.R. (4th) 193 (mandatory retirement).

R.S.C. 1985 , c. C-46.

R. v. Feeney, [1997] 3 S.C.R. 1008, 115 C.C.C. (3d) 129.

R. v. Stillman, [1997] 1 S.C.R. 607, 113 C.C.C. (3d) 321.

$R$. v. Lines, (26 April 1993) Toronto (Ont. Ct. (Gen. Div.)) [unreported].

Supra note 41.

Ibid. at s. 113(5).

Ibid. at s. 113(9). 
considerable debate. A tension has been created between the need for genuine public accountability of police actions and the concern that the duty to cooperate may force police officers suspected of crimes to provide evidence against themselves. ${ }^{63}$ It illustrates one difficulty in using the criminal process as the primary instrument of public accountability. But despite being plagued with a host of legal and operational problems, there has been insufficient legal or political will to amend the legislation. The trend to increased accountability, even where poorly accomplished, is here to stay.

\section{The Significance of the DoE JUdgment For POLICE FORCES AND THEIR GOVERNING BODIES}

Although Doe does not represent the groundbreaking case heralded by the news media, it does raise two important issues. These issues are particularly significant for police forces and the municipal police boards or other structures that serve as their public governing bodies. The first issue involves an award of damages under the Charter. The second issue involves the legal implications of an expanded duty to warn.

Authority to award damages appears in s. 24(1) of the Charter, which provides as follows:

(1) Anyone whose rights or freedoms, as guaranteed by this Charter, have been infringed or denied may apply to a court of competent jurisdiction to obtain such remedy as the court considers appropriate and just in the circumstances.

The award of $\$ 175,000$ in Doe for violation of an individual's Charter rights is highly significant. Until recently, awards of damages under s. 24(1) of the Charter have been both infrequent and modest. For example:

1. In Crossman v. The Queen, ${ }^{64}$ the plaintiff was arrested and taken to the police station where he contacted his solicitor and asked him to attend at the station. The solicitor advised the investigating officer that he would attend shortly. When the solicitor arrived and requested to see the plaintiff, police advised that they were interviewing the plaintiff, and he was not made available to speak to his lawyer until the interview concluded. No statements were obtained, and the plaintiff was permitted to speak to his lawyer at the end of the interview. The plaintiff pleaded guilty to the criminal charge but brought an action for damages on the basis that the police infringed his right to retain and instruct counsel without delay, as guaranteed by s. 10(b) of the Charter. The Federal Court ruled that the constable committed a tort against the plaintiff by interviewing him without awaiting the imminent arrival of his lawyer and also in refusing immediate access to the lawyer after he arrived. The Court awarded punitive damages of $\$ 500$. 
2. In Chrispen v. Kalinowski, ${ }^{65}$ police attended at a residence at 4:00 a.m. and executed a search warrant as part of an investigation of the plaintiff for possession of a firearm and stolen property. Police searched their records using a misspelling of the plaintiff's name and found no permit or registration for the firearm. When they later searched under the correct name, they learned the firearm was permitted and registered to the plaintiff. Six police officers entered the plaintiff's residence, two of whom had guns drawn. The court found that the police violated the plaintiff's rights to be secure against unreasonable search and seizure, as guaranteed by $\mathrm{s} .8$ of the Charter. The circumstances did not justify a night search of a private dwelling house, the degree of force used was unreasonable, the investigation into the firearm registration was careless, and police seized numerous items outside the scope of the warrant. The court awarded compensatory damages of $\$ 3,000$, together with a small amount of special damages.

3. In Krznaric v. Chevrette, ${ }^{66}$ a police officer requested employment accommodation after he developed multiple sclerosis. The employer offered some accommodation but refused to permit Krznaric to work 8-hour shifts instead of 12-hour shifts, despite appropriate medical documentation to support this request. As a result, Krznaric took sick leave and long-term disability benefits and sued the Board under s. 15(1) of the Charter. ${ }^{67}$ The Court considered several issues raised by Krznaric, and ruled in his favour on the Charter equality issue. The Court ruled that the Board was required by s. 15(1) of the Charter to accommodate reasonably the needs of disabled employees, to prevent "undue hardship." In this case, the Board failed in its duty to accommodate: 8-hour shifts would not have caused undue hardship since a senior constable could have replaced Krznaric for the remaining four hours in each shift at modest cost. The Court also concluded that the "needs of the community for police services" would not have suffered. The Court awarded damages for the loss of Krznaric's sick time credits which he used to qualify for long-term disability, together with general damages for the breach of the duty to accommodate his disability. Total damages amounted to approximately $\$ 13,000 .^{68}$

[1997] 8 W.W.R. 190, 156 Sask. R. 158 (Q.B.).

Supra note 54.

Section 15(1) provides as follows: "Every individual is equal before and under the law and has the right to the equal protection and equal benefit of the law without discrimination and, in particular, without discrimination based on race, national or ethnic origin, colour, religion, sex, age or mental or physical disability."

This judgment is under appeal. Other decisions have awarded damages, but the judgments were reversed on appeal. See Persaud v. Donaldson (1997), 32 O.R. (3d) 349, 143 D.L.R. (4th) 326 (Div. Ct.), rev'g (1995), 25 O.R. (3d) 270, 130 D.L.R. (4th) 701 (Gen. Div.). Even if the trial judgment had survived the appeal, however, the amount of damages was modest ( $\$ 3700$ for legal fees incurred to defend criminal charges). See also Freeman v. West Vancouver, (9 January 1991) (B.C.S.C.) rev'd (1992), 71 B.C.L.R. (3d) 387 (C.A.) (\$10,000 awarded at trial for violations of ss. 9 and 10). 
Sadly, the Court's s. 24(1) analysis in Doe is weak, especially in respect of an award of damages for a Charter breach. In finding that Jane Doe's Charter rights were breached, the Court explains that:

... because the defendants exercised their discretion in the investigation of this case in a discriminatory and negligent way as I have detailed above, their exercise of discretion was thereby contrary to the principle of fundamental justice.

Later, in assessing damages, the Court finds:

I am satisfied on the facts of this case that the plaintiff's damages are the same in respect of the two bases upon which her action is founded i.e. negligence and breach of Charter rights. ${ }^{69}$

The issue of the relationship between negligence and a Charter breach is never adequately clarified. The Court never tackles the difficult but important question: What level of negligence will constitute a Charter breach? Many thresholds present themselves. Simple negligence would appear untenable, at least by comparison to other fields of civil liability. But would simple negligence in the investigation of potential crimes of greater violence be appropriate? Or would gross negligence always be the hurdle? Where would legitimate exercises of discretion end and acts of negligence begin? It is precisely this kind of uncertainty that the English House of Lords rejected in Hill:

The manner of conduct of such an investigation must necessarily involve a variety of decisions to be made on matters of policy and discretion, for example as to which particular line of inquiry is most advantageously to be pursued and what is the most advantageous way to deploy the available resources. Many such decisions would not be regarded by the courts as appropriate to be called in question, yet elaborate investigation of the facts might be necessary to ascertain whether or not this was so. ${ }^{70}$

The second, equally troublesome consequence of Doe is the duty for the police to warn potential victims of crime. Unfortunately, Doe provides little guidance to police and their governing bodies in discharging this new-found duty to warn potential victims of crime. There are several issues that must be resolved. What is the extent of that duty? How far must police go to seek out potential victims and ensure the message is heard? What level of information in police hands will trigger the duty? The first examination of this issue since the Doe judgment appears in Robb v. Behiels, ${ }^{71}$ a decision of the Alberta Law Enforcement Review Board. In this case, a constable advised an employer that police were investigating a company employee for property offences, and expressed concern that the employee was misusing confidential employer information to assist in criminal activity. The Board concluded that the duty to warn

Supra note 1 at 740 .

Supra note 38 at 244. See, more recently, Osman v. Ferguson, [1993] 4 All E.R. 344 (C.A.); J. Steele \& D.S. Cowan, "The Negligent Pursuit of Public Duty - A Police Immunity?" (1994) P.L. 4.

No. 27-98, 29 September 1998. 
"may easily be extended to the context of the employer/employee relationship" 72 and police officers may be at risk if they fail to warn employers of an employee's criminal charge "where a sufficient relationship or nexus exists between the employment activity and the offence charged." ${ }^{73}$ The Board noted the "competing pressures" in this area may give rise to formal public complaints: police may risk either an allegation of misconduct for failure to discharge the duty to warn by properly notifying an employer, or a complaint that such a notification was improperly motivated and thus constitutes discreditable conduct or other misconduct. Ultimately, the Board found that the police officer acted properly in notifying the employer, given his reasonable and bona fide concern that the complainant "was in a position to assist her close associates with information of a confidential and useful nature." $" 74$

There also exists a common, yet more difficult, fact scenario in discharging a duty to warn. Doe involved an assailant whom police had yet to identify. The more common situation now facing police forces is the duty to warn communities in the case of individuals whose identities are known. One such example is paedophile offenders who are recently released from incarceration. A number of police forces have taken the view that they must notify the community-at-large of the offenders' presence, and some individuals who have been the subject of these warnings have commenced formal legal proceedings against the police. The most prominent judgment in Canada is Clubb v. Saanich (District) ${ }^{75}$ in which the British Columbia Supreme Court criticized the manner in which the police handled the release of information. Police officers performing a routine check on Clubb in a park shortly after his statutory release on a lengthy sentence for aggravated assault and sexual assault searched his vehicle and seized a camera. Police developed the film, and found nude photographs of Clubb in the park. No charges were laid, but the Parole Board revoked his parole, largely on the basis of the photographs. In particular, the Board concluded that "exhibitionist behaviour suggested ongoing sexual deviancy and that the petitioner was therefore at significant risk of reoffending." ${ }^{76}$ The chief constable issued a detailed press release, outlining Clubb's description, his criminal history and various other information. The chief constable relied on the Freedom of Information and Protection of Privacy Act, ${ }^{77}$ which provides that a public body must disclose information to the public without delay where risk of serious harm exists to the safety of the public, ${ }^{78}$ or where disclosure is clearly in the public interest. ${ }^{79}$

Clubb brought an application for judicial review, arguing in part that the police violated his right to life, liberty and security of the person, as guaranteed by s. 7 of the Charter. The Court rejected the s. 7 argument, as the only impact caused by the press release (media attention, offensive phone calls, threats and confrontations in the

Ibid. at 9 .

Ibid. at 10 .

Ibid. The Board did not conclude that the complainant did in fact do so.

(1996), 46 C.R. (4th) 253, 35 Admin. L.R. (2d) 309 (B.C.S.C.).

Ibid. at 257 [hereinafter $C l u b b$ cited to C.R.].

S.B.C. 1992 , c. 61 .

Ibid. at s. $25(1)(\mathrm{a})$.

Ibid. at s. $25(1)(\mathrm{b})$. 
penitentiary after his return) did not qualify as infringements of security of the person under s. 7. Moreover, the legislation requires a public body to ensure the accuracy of the information to be released, to notify the person to whom the information relates and to correct inaccurate information. However, the Court did conclude that the police breached the statute and the common law duty of fairness by failing to notify Clubb that his personal information was about to be disclosed, and by failing to provide an opportunity to respond to the press release before it was issued. While the person did not obtain a remedy through the judicial review process, the Court indicated that failure on the part of a public body to give proper notice to affected individuals, and permit representations, could invite exemplary or aggravated damages. Moreover, disclosure of erroneous personal information (which could occur through a failure to permit an opportunity to correct information before release), could give rise to an action in defamation.

The English Court of Appeal in R. v. Chief Constable of the North Wales Police, ex parte $A B^{80}$ also placed considerable importance on procedural fairness in release of information by the police. The applicants convicted of serious sexual assaults against several children were released from prison. They were forced to relocate on two occasions after press reports publicized their names, history and whereabouts. When the applicants settled in a "caravan site" in a third location, the local police received a report from another police force (which was partially erroneous) concerning the applicants, and became concerned at the public risk arising from their presence in the area. Accordingly, police advised the owner of the caravan site of information which had already appeared in the press, relying on their internal policy governing release of information in such circumstances. The owner ordered the applicants to leave, which they did. The applicants applied for judicial review of the decision to release information to the owner of the caravan site and of the police policy governing release of information concerning public offenders. The Court of Appeal characterized the police role in making a decision regarding public disclosure of information in such situations as "one of extreme difficulty and sensitivity":

They can be criticised for taking no or inadequate action to protect children at risk. Where they take action they can be open to criticism, either because of its effect on the ability of the offender to live a normal life or because it causes the offender to conceal his whereabouts so that children are more at risk than they would have been if this had not happened. ${ }^{81}$

\section{The Court made the following conclusion:}

Disclosure should only be made when there is a pressing need for that disclosure. Before reaching their decision as to whether to disclose the police require as much information as can reasonably practicably be obtained in the circumstances. In the majority of the situations which can be anticipated, it will be obvious that the subject of the possible disclosure will often be in the best position to provide information which will be valuable when assessing the risk. In this case the gist of what Detective 
Sergeant Lewis had learnt about the applicants should have been disclosed to them. At least consideration should have been given as to whether to disclose the report from the Northumbria Police. This did not happen and we were not made aware of any reason why there could not have been disclosure. The applicants might have had information which would have caused the detective sergeant to reassess the degree of risk. ${ }^{82}$

The question arises as to where the balance lies in such cases, and litigation against the police in this area is not expected to decrease.

Ultimately, the pace and extent of development of police civil liability as illustrated by Doe and other recent important cases and similar trends in other areas of public oversight of the police in Canada, invite a substantive response from police forces and their governing bodies. Ordinary prudence would suggest a need for increased formal legal training of police officers ${ }^{83}$ combined with increased use of competent legal advisors where issues of particular complexity arise. ${ }^{84}$

Ibid. at 68-69. The Court of Appeal noted that the probation officers involved were aware of the inaccuracies but remained of the view that the applicants created a high level of risk. In the circumstances, the Court of Appeal concluded that even if the applicants had been provided with an opportunity to comment, they could not have provided any information which would have altered the outcome.

See, for example, the decision of the Alberta Law Enforcement Review Board in Smith v. Richardson (31 December 1997), No. 35-97. The Board examined the issue of training newly recruited police officers in fundamental criminal law issues, and the need for a core training program and a "consistent, thoroughly planned and regularly adjusted" curriculum, given the extensive changes in the criminal law in the past decade. The Board also examined the issue of training experienced police officers as "... some line officers are not aware of the vast changes that have occurred in the criminal law over the last several years and ... others appear only to have a passing interest in that reality" (Smith, ibid. at 16-17). Such comments would seem to apply equally to legal issues in policing outside of pure criminal law, such as those arising in the Doe case. 